\title{
HUBUNGAN TINGKAT PENGETAHUAN TENTANG NARKOBA DAN STIGMA PADA PECANDU NARKOBA DENGAN MOTIVASI TIDAK MEMAKAI NARKOBA PADA REMAJA
}

\author{
Endang Dwi Ningsih', Emanuela Veren Gravita Kusuma²
}

\begin{abstract}
Background: The circulation of drugs in Indonesia has penetrated in all of the society levels, this condition is very worrying for the sustainability of the nation. The prevalence of drug abuse in group of students and college students in 2016 is $3.8 \%$, where every year experiencing significant fluctuations. Related to the above, it is necessary to research about the relationship between the level of knowledge about drugs and the stigma of drug addicts with the motivation not to use drugs in teenagers GBI Emunah Solo Baru Sukoharjo.

Objective: To know the correlation between the level of knowledge about drugs and stigma on drug addicts with the motivation not to use drugs in adolescents.

Research Subject: Research sample are 63 teenagers / youth of GBI Emunah Solo Baru Sukoharjo by using Saturation sampling technique.

Research Subject: Research sample are 63 teenagers / youth of GBI Emunah Solo Baru Sukoharjo by using Saturation sampling technique.

Result of the research: By Bivariate test obtained the result $p=0.000$ and $p<0.05$. By Multivariate test obtained result of value Negelkerke Square $60.3 \%$

Conclusion: There is a relationship between the level of knowledge about drugs with the motivation of not using drugs, and there is also a relationship between the stigma of drug addicts with the motivation not to use drugs. That the level of knowledge about drugs and stigma in drug addicts together related to non-drug motivation $60.3 \%$ while the remaining $39.7 \%$ influenced by other variables outside the study.
\end{abstract}

Keywords: Motivation not to use drugs, stigma in drug addicts and level of knowledge about drugs

\section{PENDAHULUAN}

Peredaran narkoba di Indonesia sudah merambah pada seluruh lapisan masyarakat, kondisi seperti ini sangat menghawatirkan untuk keberlangsungan

bangsa.

Sebagaimana yang ditayangkan pada MetroTV bahwa Indonesia menjadi target peredaran narkoba terbesar di Asia karena demand dan keuntungan yang besar serta hukuman yang ringan, bahkan

$80 \%$ penghuni Lapas juga pemakai narkoba, jaringan narkoba di lapas sudah sangat canggih alat-alatnya menggunakan satelit sehingga tidak dapat dideteksi oleh alat Lapas yang masih sederhana.

Sebagaimana Survei Nasional Perkembangan Penyalahgunaan dan Peredaran Gelap Narkoba pada kelompok pelajar dan mahasiswa di 16 Provinsi di Indonesia Tahun 2011 menunjukkan bahwa $4.3 \%$ pelajar/mahasiswa Indonesia pernah menggunakan narkoba. Bahkan remaja Indonesia saat ini tidak hanya berstatus sebagai pemakai tetapi juga pengedar (Riyadi, 2015). Peningkatan penggunaan narkoba pada remaja sekarang ini sudah sering dijumpai di berbagai media sosial dan media cetak. Data BNN menunjukkan jumlah pengguna narkoba di Indonesia hingga Nopember 2016 mencapai 5.9 juta orang. Prevalensi penyalahgunaan narkoba pada kelompok pelajar dan mahasiswa tahun 2016 yaitu $3.8 \%$, dimana setiap tahun mengalami fluktuasi yang signifikan (Sunaryo, 2017). 
Penyebab utama seseorang terlibat dalam penyalahgunaan narkoba yaitu rasa ingin tahu/rasa penasaran yang besar tanpa menyadari akibatnya. Biasanya seseorang menyalahgunakan narkoba melalui lima tahap yaitu coba-coba untuk memenuhi rasa ingin tahu, menggunakan narkoba hanya pada saat bergaul agar diterima oleh lingkungan pergaulan, menggunakan narkoba pada saat kesal, sedih dan kecewa, menggunakan narkoba semakin meningkat tanpa alasan pergaulan atau sedang bermasalah dan yang terakhir adalah menggunakan narkoba menjadi kebutuhan hidup (Nashshar, 2009).

NAPZA adalah narkotika, alkohol, psikotropika, dan zat adiktif lainnya. NAPZA erat kaitannya dengan masalah sosial yang terjadi di tiap negara. Bahan-bahan NAPZA tidak boleh digunakan secara bebas karena dapat mengakibatkan adiksi/kecanduan, yang ditandai dengan melemahnya kemampuan individu untuk beraktivitas normal dan berpikir sehat. Seseorang yang telah adiktif, sangat kuat kemungkinan untuk melakukan kekerasan terhadap keluarga maupun lingkungan untuk mendapatkan apa yang menjadi keinginannya (Noorkasiani, Heryati, dan Ismail, 2009).

Salah satu yang meresahkan masyarakat dan diprediksi akan memberikan masalah serius pada permasalahan bangsa adalah dekadensi moral. Selain krisis ekonomi tahun 1998, sebelum terjadinya krisis itu, dekadensi moral mulai ramai dibicarakan, terutama seks bebas dan narkoba. Narkotika dan obat-obatan terlarang (narkoba) adalah momok bak teroris yang akan mengancam generasi muda. Penyalahgunaan dan peredaran narkoba semakin merajalela dan telah menimbulkan banyak korban jiwa, harta, dan moral anak bangsa, yang menimbulkan kegelisahan, ketakutan dan kecemasan di kalangan masyarakat, pendidik, ulama hingga para pejabat (Siswaya, 2008). Pengalaman empirik membuktikan bahwa kriminalisasi penyalahgunaan narkoba tidak menyelesaikan masalah justru stigma masyarakat terhadap pecandu narkoba sebagai penjahat yang harus dijauhi agar tidak menular. Stigma merupakan pandangan negatif masyarakat terhadap suatu hal atau individu termasuk pecandu narkoba. Hal inilah yang membuat pecandu narkoba semakin sulit untuk mendapat bantuan dan dukungan dalam penyembuhan, walaupun sudah berhentipun tetap diperlakukan sama di masyarakat dianggap sampah masyarakat yang patut disingkirkan, yang akhirnya akan berdampak timbulnya perilaku kriminal yang lebih berat.

Pengetahuan adalah suatu pembentukan yang terus menerus oleh seseorang yang setiap saat mengalami reorganisasi karena adanya pemahaman baru (Widianti, 2007). Pengetahuan terjadi setelah orang mengadakan pengindraan terhadap objek tertentu melalui panca indra manusia. Pada waktu pengindraan sampai menghasilkan pengetahuan tersebut sangat dipengaruhi oleh intensitas perhatian persepsi terhadap objek (Wawan dan Dewi, 2011).

Sebagaimana kutipan dalam penelitian yang dilakukan Sunaryo (2017) bahwa, pengetahuan merupakan unsur utama pembentuk perilaku seseorang. Pengetahuan merupakan proses kognitif dari seseorang untuk memberi arti terhadap lingkungan, sehingga masing-masing individu akan memberi arti sendiri-sendiri terhadap stimulus yang diterimanya meskipun stimulusnya sama. Pengetahuan atau kognitif merupakan domain yang sangat penting untuk 
terbentuknya tindakan seseorang atau ovent behavior (Wawan dan Dewi, 2011).

Pada penelitian yang dilakukan oleh Zaen, Azizah dan Warseno (2017), menyimpulkan terdapat hubungan antara tingkat pengetahuan dengan sikap menghindari diri dari penyalahgunaan NAPZA dengan hasil penelitian bahwa tingkat pengetahuan siswa tentang narkoba lebih banyak pada kategori cukup (70.2\%) dengan sikap menghindari diri dari penyalahgunaan NAPZA mayoritas tinggi (97.6\%) maka disarankan pihak sekolah dapat memfasilitasi adanya penyuluhan tentang bahaya NAPZA serta pengawasan terhadap siswa dengan bekerjasama dengan keluarganya. Demikian halnya pada Penelitian yang dilakukan oleh Fazbir dan Syaifudin (2017), menyatakan ada hubungan antara tingkat pengetahuan dan kecerdasan spiritual remaja dengan sikap kecenderungan penyalahgunaan NAPZA di SMKN 1 Siniu Sulawesi Tengah dengan menggunakan Product Moment nilai $p=0.000$ dan $p$ lebih kecil dari 0.05 .

Motif merupakan tenaga pendorong yang mendorong manusia untuk bertindak atau suatu tenaga di dalam diri manusia, yang menyebabkan manusia bertindak atau melakukan sesuatu. Motivasi adalah serangkaian sikap dan nilainilai yang mempengaruhi individu untuk mencapai hal yang spesifik sesuai tujuan individu (Donsu, 2017). Sedangkan menurut Effendy dan Nursalam (2008) motivasi dapat diartikan sebagai dorongan internal dan eksternal dalam diri seseorang yang diindikasikan dengan adanya hasrat dan minat untuk melakukan kegiatan.

Beberapa hal yang menyebabkan remaja menggunakan narkoba adalah karena munculnya budaya mencari kenikmatan, kepribadian remaja, tekanan kelompok sebaya, keterasingan remaja, stres dan rasa tidak aman serta penilaian pada diri sendiri. Biasanya remaja laki-laki lebih rentan mengkonsumsi narkoba dibanding remaja perempuan, hal ini dipengaruhi aspek lingkungan remaja laki-laki lebih luas jaringan sosialnya dan aspek psikologis yakni gangguan perilaku yang mengakibatkan remaja laki-laki memiliki motivasi yang rendah untuk tidak menggunakan narkoba (Hani, 2011). Pada penelitian yang dilakukan Putra dan Sukoco (2011) dinyatakan bahwa ada hubungan antara dukungan sosial dengan motivasi untuk sembuh pada pengguna NAPZA di Rehabilitasi Madani Mental Health Care dengan menggunakan uji korelasi Pearson didapatkan $r$ hitung 0.435 dengan signifikasi $0.001<0.01$, maka keputusannya adalah menerima hipotesis dan koefisien determinasi $R$ Square $\left(\mathrm{R}^{2}\right)$ sebesar 0.275 . Artinya seluruh aspek dukungan sosial memberikan sumbangsih sebesar $27.5 \%$ terhadap motivasi untuk sembuh. Dengan demikian $72.5 \%$ sisanya dapat dijelaskan oleh variabel lain selain dukungan sosial. Demikian halnya penelitian yang dilakukan oleh Shidqi (2014), bahwa tayangan video anti narkoba berpengaruh terhadap sikap remaja pada NAPZA di Dusun Pratan Kelurahan Sinduadi Kecamatan Mlati Kabupaten Sleman Yogyakarta dengan hasil uji statistik menunjukkan nilai mean 110.76 untuk pre test dan 126.20 untuk post test dan selanjutnya diperoleh signifikasi $p=0.000$ dan $p<0.05$.

Berdasarkan data yang diperoleh dari wawancara pada 6 (enam) remaja/pemuda di GBI Emunah Solo Baru diperoleh informasi bahwa mereka takut dan ngeri kalau melihat dampak narkoba pada media sosial. Mereka mengatakan orang yang terkena narkoba masa depannya akan hancur maka 
mereka merasa tidak perlu berteman dengan orang yang menggunakan narkoba, takut tertular atau takut diberi stigma negatif oleh masyarakat. Pada saat peneliti menanyakan tentang pengetahuan narkoba lebih detail dan berapa besar motivasi untuk tidak memakai narkoba, remaja/pemuda tersebut menyebut ganja, heroin dan sabu-sabu, untuk jenis lainnya tidak tahu karena tidak pernah mendalami dengan sungguh-sungguh tentang pengetahuan tersebut. Adapun motivasi untuk tidak memakai narkoba hanya dijawab tidak ingin, merasa tidak pernah terlintas dalam pikirannya tentang narkoba. Para remaja/pemuda ini tidak mampu memberi jawaban yang pasti karena selama ini juga belum pernah dilakukan panelitian.

Dari latar belakang tersebut di atas, dirasa perlu adanya penelitian tentang hubungan tingkat pengetahuan tentang narkoba dan stigma pada pecandu narkoba dengan motivasi tidak memakai narkoba pada remaja/pemuda GBI Emunah Solo Baru Sukoharjo.

Penelitian ini merupakan replika penelitian sebelumnya, namun memiliki perbedaan dalam hal lokasi penelitian dan memasukkan variabel tentang stigma pada pecandu narkoba untuk mengetahui sejauhmana penolakan atau penerimaan remaja/pemuda tentang pecandu narkoba, karena dari sikap inilah dapat diketahui motivasi tidak memakai narkoba dan cara penanganan bila menghadapi para pecandu narkoba.

\section{TUJUAN PENELITIAN}

Secara umum penelitian ini bertujuan untuk mengetahui hubungan tingkat pengetahuan tentang narkoba dan stigma pada pecandu narkoba dengan motivasi tidak memakai narkoba pada remaja. Sedangkan tujuan khusus penelitian ini adalah untuk mengetahui tingkat pengetahuan tentang narkoba pada remaja, mengetahui gambaran pemberian stigma pada pecandu narkoba oleh remaja, mengetahui tingkat motivasi tidak memakai narkoba pada remaja dan mengetahui hubungan antara tingkat pengetahuan tentang narkoba dengan motivasi tidak memakai narkoba, serta untuk mengetahui hubungan tentang stigma pada pecandu narkoba dengan motivasi tidak memakai narkoba.

\section{METODE/DESAIN PENELITIAN}

Penelitian ini merupakan penelitian analitik dengan desain korelasi dan melibatkan tiga variabel yang bertujuan untuk mengkaji hubungan tingkat pengetahuan tentang narkoba dan stigma pada pecandu narkoba sebagai variabel bebas (independent variable) dengan motivasi tidak memakai narkoba sebagai variabel terikat (dependent variable).

\section{POPULASI, SAMPEL DAN TEKNIK SAMPLING}

Populasi pada penelitian ini adalah remaja/pemuda GBI Emunah Solo Baru Sukoharjo yang berjumlah 63 orang yang kemudian diambil sebagai sampel dengan menggunakan teknik sampling jenuh yaitu dengan mengambil semua anggota populasi menjadi sampel.

\section{HASIL PENELITIAN}

Di bawah ini akan dipaparkan karakteristik responden berdasarkan jenis kelamin, usia dan pendidikan adalah sebagai berikut : 
Tabel 1.

Distribusi Karakteristik Responden Berdasarkan Jenis Kelamin, Usia dan Tingkat Pendidikan.

\begin{tabular}{lccc}
\hline Karakteristik & Kategori & $\mathrm{f}$ & $\%$ \\
\hline Jenis & Laki-laki & 29 & 46 \\
Kelamin & Perempuan & 34 & 54 \\
Usia & $15-20$ tahun & 34 & 54 \\
& $21-30$ tahun & 27 & 43 \\
& $>30$ tahun & 2 & 3 \\
Tingkat & PT & 26 & 41 \\
Pendidikan & SMA/SMK & 37 & 59 \\
\hline
\end{tabular}

Dari tabel di atas menunjukkan bahwa sebagian besar responden berjenis kelamin perempuan berjumlah 34 orang (54\%) dan jumlah responden berjenis kelamin laki-laki berjumlah 29 orang (46\%). Sedangkan karakteristik berdasarkan usia sebagian besar responden berusia 15 - 20 tahun berjumlah 34 orang (54\%) dan responden yang berusia paling sedikit > 30 tahun berjumlah 2 orang (3\%). Untuk tingkat pendidikan pada tingkat perguruan tinggi 26 orang (41\%) dan tingkat SMA/SMK sejumlah 37 orang (59\%).

Tabel 2.

Distribusi Frekuensi Variabel Penelitian

\begin{tabular}{lccc}
\hline \multicolumn{1}{c}{ Variabel } & Kategori & $\mathrm{f}$ & $\%$ \\
\hline Tingkat & Tinggi & 46 & 73 \\
pengetahuan & Rendah & 17 & 27 \\
Stigma pada & Tinggi & 48 & 76.2 \\
pecandu & Rendah & 15 & 23.8 \\
narkoba & & & \\
Motivasi tidak & Tinggi & 40 & 63.5 \\
memakai & Rendah & 23 & 36.5 \\
narkoba &
\end{tabular}

Dari tabel di atas dapat diperoleh data bahwa:

a. Tingkat pengetahuan remaja/pemuda tentang narkoba kategori tinggi sejumlah 46 orang $(73 \%)$ sedang kategori rendah sejumlah 17 orang (27\%). b. Stigma remaja/pemuda pada pecandu narkoba kategori tinggi sejumlah 48 orang (76.2\%) sedang kategori rendah sejumlah 15 orang (23.8\%).

c. Motivasi tidak memakai narkoba kategori tinggi sejumlah 40 orang $(63.5 \%)$ sedang kategori rendah sejumlah 23 orang (36.5\%).

Tabel 3.

Tabulasi Silang Tiap Variabel Bebas Terhadap Variabel Terikat Motivasi

Variabel Kategori tidak memakai narkoba

\begin{tabular}{lcccc} 
& & Tinggi & Rendah & Total \\
\cline { 3 - 5 } Tingkat & Tinggi & 39 & 7 & 46 \\
penge- & $(84.8)$ & $(15.2)$ & $(100)$ \\
tahuan & & 1 & 16 & 17 \\
& Rendah & $(5.9)$ & $(94.1)$ & $(100)$ \\
Stigma & & 38 & 10 & 48 \\
pada & Tinggi & $(79.2)$ & $(20.8$ & $(100)$ \\
pecandu & & 2 & 13 & 15 \\
narkoba & Rendah & $(13.3)$ & $(86.7)$ & $(100)$ \\
& & $(10)$
\end{tabular}

Berdasarkan tabel di atas dapat dilihat bahwa :

a. Pada hubungan tingkat pengetahuan tentang narkoba dengan motivasi tidak memakai narkoba.

1) Terdapat responden yang memiliki tingkat pengetahuan tinggi sejumlah 46 orang, 39 orang $(84.8 \%)$ memiliki motivasi tinggi dan 7 orang $(15.2 \%)$ memiliki motivasi rendah.

2) Terdapat responden yang memiliki tingkat pengetahuan rendah sejumlah 17 orang, 1 orang $(5.9 \%)$ memiliki motivasi tinggi dan 16 orang (94.1\%) memiliki motivasi rendah.

Berdasarkan hasil uji dengan menggunakan Chi Square dengan $\alpha=5 \%$ (0.05) diperoleh $p=0.000$ menunjukkan bahwa ada hubungan antara tingkat pengetahuan tentang narkoba dengan motivasi tidak memakai narkoba. 
b. Pada hubungan tentang stigma pada pecandu narkoba dengan motivasi tidak memakai narkoba.

1) Terdapat responden yang memiliki stigma tinggi sejumlah 48 orang, 38 orang $(79.2 \%)$ memiliki motivasi tinggi dan 10 orang (20.8\%) memiliki motivasi rendah

2) Terdapat responden yang memiliki stigma rendah sejumlah 15 orang, 2 orang $(13.3 \%)$ memiliki motivasi tinggi dan 13 orang (86.7\%) memiliki motivasi rendah

Berdasarkan hasil uji dengan menggunakan Chi Square dengan $\alpha=5 \% \quad(0.05)$ diperoleh $p=0.000$ menunjukkan bahwa ada hubungan antara stigma remaja/pemuda pada pecandu narkoba dengan motivasi tidak memakai narkoba.

Berdasarkan hasil bivariat maka semua variabel menunjukkan hasil $p$ $<0.05$ maka semua variabel dapat dianalisis dengan uji multivariat karena $p<0.25$.

Hasil analisa multivariat pada penelitian ini menunjukkan variabel independen mempengaruhi variabel dependen dengan nilai Nagelkerke $R$ Square $60.3 \%$ artinya bahwa variabel tingkat pengetahuan tentang narkoba dan gambaran stigma pada pecandu narkoba secara bersama-sama berhubungan dengan motivasi tidak memakai narkoba sebesar $60.3 \%$ dan sisanya yang $39.7 \%$ dipengaruhi variabel lain di luar penelitian.

\section{PEMBAHASAN}

Berdasarkan Tabel 2, sebagian sebagian besar remaja/pemuda memiliki tingkat pengetahuan yang tinggi tentang narkoba yaitu sebesar $73 \%$. Sebagaimana yang dikemukakan oleh Wawan dan Dewi (2011), banyak faktor yang mempengaruhi diperolehnya informasi pengetahuan seseorang.
Antara lain karena pendidikan, pekerjaan, usia, lingkungan dan sosial budaya. Pengaruh tingkat pendidikan, usia dan pekerjaan dapat dilihat bahwa tingkat pendidikan responden $41 \%$ dari perguruan tinggi dan $59 \%$ dari SMA/SMK serta dari segi usia pada usia 15 - 43 tahun, semakin tinggi pendidikan seseorang makin mudah menerima informasi dan semakin bertambah usia seseorang akan menunjukkan tingkat kedewasaannya terlebih bila responden sudah bekerja maka tingkat kematangannya makin terbentuk. Adapun pengaruh lingkungan dan sosial budaya yang membentuk tingkat pengetahuan responden karena makin maraknya perbincangan tentang topik narkoba dan cara-cara pencegahannya melalui media: televisi, radio, dan media digital lain, atau mungkin melalui komunitas - komunitas tertentu, terlebih sebagaimana yang disampaikan oleh Siswaya (2008) bahwa masalah NAPZA selalu berkaitan dengan permasalahan bangsa yang menyangkut dekadensi moral menyangkut seks bebas dan penyalahgunaan obatobat terlarang, maka hal tersebut telah menjadi momok yang mengancam generasi muda, sehingga sangat dimungkinkan mudahnya diperoleh informasi tentang narkoba. Sebagaimana dikutip oleh Sunaryo (2017) bahwa pengetahuan merupakan proses kognitif dari seseorang untuk memberi arti terhadap lingkungan, dalam hal ini responden belajar dari lingkungannya atau komunitasnya. Para remaja/pemuda perlu mengetahui pengetahuan yang menyangkut narkoba, agar tidak terjerumus atau bahkan menyalahgunakan obat yang termasuk berbahaya. NAPZA merupakan obat yang mempengaruhi saraf/otak, apabila disalahgunakan akan menimbulkan 
ketagihan dan merusak serta menimbulkan ketidakmampuan fungsi sosial, pekerjaan dan sekolah (Sugiharsono, et al., 2008). Demikian halnya yang disampaikan oleh Efendi dan Makhfudli (2009), bahwa NAPZA menyebabkan terganggunya fungsi kognitif, persepsi, daya nilai perilaku dan ketergantungan fisik maupun psikis.

Dari hasil uji bivariat dapat diperoleh $p=0.000$ dan $p<0.05$ artinya ada hubungan antara tingkat pengetahuan tentang narkoba dengan motivasi tidak memakai narkoba, hal ini dapat dilihat pada tabel 3 dari 46 orang yang memiliki pengetahuan kategori tinggi terdapat $84.8 \%$ responden memiliki motivasi tinggi tidak memakai narkoba, hal ini sesuai yang diungkapkan oleh Widianti (2007) bahwa pengetahuan terbentuk melalui proses yang terus-menerus yang setiap saat akan mengalami reorganisasi karena adanya pemahaman yang baru. Pengetahuan merupakan unsur utama pembentukan perilaku seseorang (Sunaryo, 2017) maka semakin tinggi tingkat pengetahuan semakin positif pula motivasinya yang akhirnya akan memunculkan perilaku yang positif dan semakin rendah pengetahuan narkoba seseorang, motivasi tidak memakai narkoba kategori rendah makin tinggi, hal ini dapat dilihat pada tabel 3. dari 17 orang yang tingkat pengetahuannya rendah terdapat $94.1 \%$ yang memiliki motivasi rendah tidak memakai narkoba. Dari kutipan Sobur (2011), dinyatakan bahwa motivasi merupakan dorongan yang timbul yang tujuan akhirnya adalah perbuatan, sedangkan perbuatan/perilaku yang didasari oleh pengetahuan akan bersifat lebih langgeng (Wawan dan Dewi (2011). Jadi bila tingkat pengetahuan semakin baik semakin baik pula motivasi responden untuk tidak memakai narkoba sebagaimana hasil penelitian Zaen, Azizah dan Warseno ( 2017), bahwa tingkat pengetahuan tentang narkoba lebih banyak pada kategori cukup (70.2\%) dan sikap menghindari dari penyalahgunaan narkoba mayoritas tinggi (97.6\%).

Pada penelitian yang dilakukan oleh Fazbir dan Syaifudin (2017) membuktikan bahwa ada hubungan antara tingkat pengetahuan dan kecerdasan spiritual remaja dengan sikap kecenderungan penyalahgunaan NAPZA di SMKN I Siniu Sulawesi.

Pada Tabel 2 ini juga didapatkan 48 orang (76.2\%) responden memberikan stigma tinggi pada pecandu narkoba. Menurut Ardhiyanti, Lusiana dan Megasari (2015), stigma merupakan bentuk prasangka yang mendiskreditkan, pandangan negatif atau menolak seseorang, stigma berhubungan dengan struktur masyarakat dan nilai/norma yang mengatur kehidupan sehari-hari. Seseorang yang telah adiktif/ kecanduan narkoba sangat kuat dimungkinkan melakukan kekerasan terhadap keluarga maupun lingkungan sebagaimana kutipan Heryati dan Ismail (2009), hal ini semakin membuat takut dan cemas kalangan masyarakat, pendidik dan ulama (Siswaya, 2008). Pada pengamatan peneliti terhadap responden, karena sampel yang diteliti adalah lingkungan gerejani maka remaja/pemudanya tentunya sangat ditekankan pada ajaran-ajaran agama tentang bagaimana menghindari pergaulan yang menjerumuskan manusia pada moral yang tidak baik, sehingga dampak gambaran stigma remaja/pemuda pada pecandu narkoba sangat tinggi, hal tersebut bukan karena antipati atau memusuhi tetapi karena besarnya dampak negatif dari penyalahgunaan NAPZA seperti yang disampaikan oleh Siswaya 
(2008), bagi pecandu narkoba sendiri akan terjadi perubahan perilaku anti sosial, merosotnya produktivitas kerja, gangguan kesehatan dan berubah emosional sedang bagi keluarga akan berdampak dari rasa malu, hidup tidak tenang, uang terkuras untuk penyembuhan dan menghancurkan nama baik keluarga. Bagi seseorang yang sudah mengalami kecanduan narkoba, seringkali keluarga sendiri merasa kesulitan dalam melakukan bimbingan atau memberi motivasi sembuh, hal ini sesuai hasil penelitian Putra dan Sukoco (2011) bahwa dukungan sosial hanya memberi sumbangsih sebesar $27.5 \%$ terhadap motivasi untuk sembuh pada pengguna NAPZA di Rehabilitasi Madani Mental Health Care.

Dari hasil uji bivariat dapat diperoleh $p=0.000$ dan $p<0.05$ artinya ada hubungan antara stigma pada pecandu narkoba dengan motivasi untuk tidak memakai narkoba, hal ini dapat dilihat pada tabel 3 dari 48 orang responden yang memiliki stigma tinggi terhadap pecandu narkoba, $79.2 \%$ memiliki motivasi tinggi untuk tidak memakai narkoba, hal ini sesuai yang diungkapkan oleh Ardhiyanti, Lusiana dan Megasari (2015), bahwa penyalahgunaan narkoba merupakan penjahat/kriminal, sampah masyarakat yang harus dijauhi agar tidak menular, maka semakin kuat stigma pada pecandu narkoba semakin sulit diterima di lingkungan masyarakat.

Stigma yang tinggi responden terhadap pecandu narkoba memberi dorongan untuk menghindari stigma yaitu dengan tidak bersentuhan dengan masalah narkoba bahkan responden merasa tidak pernah terlintas dalam pikirannya tentang narkoba, hal ini menunjukkan sikap yang positif dan memunculkan motivasi yang positif untuk tidak memakai narkoba. Sebagaimana disampaikan oleh Donsu (2017), bahwa fungsi motivasi sebagai penggerak, menentukan arah perbuatan dan menentukan perbuatan apa yang harus dikerjakan dengan menyisihkan perbuatan yang tidak bermanfaat. Berdasarkan hasil penelitian yang dilakukan oleh Shidqi (2014) bahwa tayangan video anti narkoba berpengaruh pada sikap untuk tidak menyalahgunakan narkoba pada remaja Dusun Pratan Sleman, dengan melihat tayangan video anti narkoba tentunya akan memunculkan sikap antipati (stigma) terhadap narkoba dan memberi pemahaman tentang bahayanya masalah narkoba sehingga memunculkan sikap untuk tidak menyalahgunakan narkoba dan munculnya motivasi tidak ingin memakai narkoba.

Hasil penelitian menunjukkan variabel independen mempengaruhi variabel dependen dapat dilihat dengan nilai Nagelkerke $R$ Square $60,3 \%$ artinya bahwa bahwa variabel tingkat pengetahuan tentang narkoba dan gambaran stigma pada pecandu narkoba secara bersama-sama berhubungan dengan motivasi tidak memakai narkoba sebesar $60.3 \%$ dan sisanya yang $39.7 \%$ dipengaruhi variabel lain di luar penelitian. Tingkat pengetahuan yang tinggi pada responden dan stigma yang tinggi responden terhadap pecandu narkoba memberikan motivasi yang kuat untuk tidak memakai narkoba, hal ini dapat dilihat dari tabel 2 yang memiliki motivasi tinggi untuk tidak memakai narkoba 40 orang (63.5\%). Jadi tingkat pengetahuan tentang narkoba dan stigma pada pada pecandu narkoba memberi pemahaman yang benar dan motivasi positif, sebagaimana yang disampaikan oleh Wawan dan Dewi (2011) bahwa domain kognitif pada tingkat memahami akan memberi kemampuan untuk menjelaskan 
secara benar obyek yang diketahui dan mampu menginterprestasikan secara benar pula karena pengetahuan dan kognitif yang benar merupakan domain yang sangat penting untuk terbentuknya tindakan seseorang. Hal ini diperkuat oleh pendapat Notoatmodjo (2011), bahwa pengadopsian perilaku yang didasari oleh pengetahuan, kesadaran yang positif akan memunculkan perilaku yang langgeng (long lasting).

\section{KESIMPULAN}

Dari hasil penelitian yang berjudul hubungan tingkat pengetahuan tentang narkoba dan stigma pada pecandu narkoba dengan motivasi tidak memakai narkoba pada remaja/pemuda GBI Emunah Solo Baru Sukoharjo dapat diperoleh kesimpulan sebagai berikut:

1. Terdapat tingkat pengetahuan remaja/pemuda tentang narkoba kategori tinggi sejumlah 46 orang (73\%) sedang kategori rendah sejumlah 17 orang (27\%).

2. Stigma remaja/pemuda pada pecandu narkoba kategori tinggi sejumlah 48 orang $(76.2 \%)$ sedang kategori rendah sejumlah 15 orang $(23.8 \%)$.

3. Motivasi tidak memakai narkoba kategori tinggi sejumlah 40 orang $(63.5 \%)$ sedang kategori rendah sejumlah 23 orang (36.5\%).

4. Tingkat pengetahuan tentang narkoba berhubungan dengan motivasi tidak memakai narkoba $(p=0.000$ dan $p<0.05$ ).

5. Stigma pada pecandu narkoba berhubungan dengan motivasi tidak memakai narkoba $(p=$ 0.000 dan $p<0.05$ ).

6. Hasil analisa multivariat menunjukkan variabel independen mempengaruhi variabel dependen dengan nilai Nagelkerke $R$ Square $60.3 \%$ artinya bahwa variabel tingkat pengetahuan tentang narkoba dan gambaran stigma pada pecandu narkoba secara bersama-sama berhubungan dengan motivasi tidak memakai narkoba sebesar $60.3 \%$ dan sisanya yang $39.7 \%$ dipengaruhi variabel lain di luar penelitian.

\section{SARAN}

1. Agar remaja/pemuda mampu memiliki motivasi tidak memakai narkoba, maka harus ditingkatkan tingkat pengetahuan dan stigma terhadap pecandu narkoba sehingga memiliki pemahaman yang benar tentang perilaku menyimpang tersebut dan remaja/pemuda dapat terhindar dari penyalahgunaan narkoba.

2. Bagi institusi pendidikan keperawatan, diharapkan dapat melakukan penyuluhan tentang pencegahan terhadap penyalahgunaan narkoba.

3. Untuk peneliti selanjutnya diharapkan dapat mengembangkan faktor-faktor lain yang belum diteliti yang berhubungan dengan penanggulangan narkoba.

\section{DAFTAR PUSTAKA}

Ardhiyanti, Y., N. Lusiana dan K. Megasari. 2015. Bahan ajar AIDS pada Asuhan Keperawatan Kebidanan. https://book.google.co.id/books? id=ej. Dilihat pada tanggal 28 oktober 2017.

Donsu, J. D. T. 2017. Psikologi Keperawatan. Pustaka Baru Press, Yogyakarta.

Effendi, F. dan Makhfudli. 2009. Keperawatan Kesehatan Komunitas Teori dan Praktik dalam Keperawatan. https://books.google.co.id/books Dilihat pada tanggal 3 September 2017. 
Effendi, Ferry dan Nursalam. 2008. Pendidikan dalam Keperawatan. Salemba Medika, Jakarta.

Fazbir, M. dan Syaifudin. Hubungan Tingkat Pengetahuan dan Kecerdasan Spiritual Remaja dengan Sikap Kecenderungan Penyalahgunaan NAPZA di SMKN 1 Siniu Sulawesi Tengah. Opac.say.ac.id.pdf. Diakses tanggal 6 oktober 2018.

Hani, Tz. 2011. Remaja dan Narkoba.

https://www.kompasiana.com. Diakses tanggal 6 Oktober 2018 Joko. 2007. Hindari NAPZA. Mediatama, Surakarta.

Nashshar. 2009. Memahami Masalah Penyimpangan Sosial. Puri Pustaka, Bandung.

Noorkasiani, Heryati, dan Rita Ismail. 2009. Sosiologi Keperawatan.

https://books.google.co.id/ books?id. Diakses pada tanggal 5 September 2017.

Notoatmodjo, S. 2011. Kesehatan Masyarakat IImu dan Seni. Rineka Cipta, Jakarta.

Putra, Bayu dan Sukoco. 2011. Hubungan Antara Dukungan Sosial dengan Motivasi untuk Sembuh pada Pengguna NAPZA di Rehabilitasi Madani Mental Health Care. repository.uinsyarifhidayatullah. Diunduh pada tanggal 8 September 2017.

Riyadi, A. 2015. Resiko Penyalahgunaan NAPZA pada Remaja ditinjau dari Jenis Kelamin, Status Tinggal dan Status Orang Tua. UMSETD$d b$. Volume 1. Diunduh pada tanggal 9 September 2017.

Siswaya, et al. 2008. Drug and Drink, Cara Menjauhinya. Suara Media Sejahtera, Surakarta.
Shidqi, M. 2014. Pengaruh Tayangan Video Anti Narkoba terhadap Sikap Remaja pada NAPZA (Studi Eksperimen pada Remaja Dusun Patran Kelurahan Sinduadi Kecamatan Mlati Kabupaten Sleman). Digital Library UIN Sunan Kalijaga. Volume 1. Diunduh pada tanggal 8 September 2017

Sobur, A. 2011. Psikologi Umum. Pustaka Setia, Bandung.

Sugiharsono, et al. 2008. IImu Pengetahuan Sosial. https:// books. google. co.id/books?id. Diakses pada tanggal 6 Oktober 2017.

Sunaryo, S. 2017. Hubungan Tingkat Pengetahuan Remaja Tentang Narkoba dan Sikap menggunakan Narkoba pada SMA di Kabupaten Sleman.

Jurnal.stikes.wirahusada.ac.id.pdf. Diakses tanggal 10 Nopember 2017

Widianti, E. 2007. Remaja dan permasalahannya: bahaya merokok, penyimpangan seks pada remaja dan bahaya penyalahgunaan narkoba. Available. https://elib.unikom.ac.id/files/dis k.pdf. Diakses tanggal 10 Oktober 2017.

Wawan A. dan Dewi M. 2011. Pengetahuan, Sikap dan Perilaku Manusia. Nuha Medika, Yogyakarta.

Zaen, Aprian Zam, Fajriati Nur Azizah dan Agus Warseno. Hubungan antara Tingkat Pengetahuan dengan Sikap Siswa tentang Penyalahgunaan NAPZA di SMA Negeri I Sleman Yogyakarta. repositori.stikesayaniyk.ac.id.pdf. Diakses 5 oktober 2017.

${ }^{1}$ Dosen AKPER Panti Kosala

Surakarta

${ }^{2}$ Mahasiswa AKPER Panti Kosala

Surakarta 